\title{
Review
}

\section{p53/p63/p73 isoforms: an orchestra of isoforms to harmonise cell differentiation and response to stress}

\author{
F Murray-Zmijewski ${ }^{1}$, DP Lane ${ }^{1}$ and J-C Bourdon ${ }^{\star, 1}$ \\ ${ }^{1}$ Department of Surgery and Molecular Oncology, University of Dundee, \\ Ninewells Hospital, CR-UK Cell Transformation Research Group, Dundee \\ DD19SY, UK \\ * Corresponding author: J-C Bourdon, Department of Surgery and Molecular \\ Oncology, University of Dundee, CR-UK Cell Transformation Research Group, \\ Ninewells Hospital, Dundee DD1 9SY, UK. Tel: + 44-1382-496400; \\ Fax: + 44-1382-496363; E-mail: j.bourdon@dundee.ac.uk
}

Received 25.1.06; accepted 03.2.06; published online 07.4.06 Edited by RA Knight

\begin{abstract}
p63, p73 and p53 compose a family of transcription factors involved in cell response to stress and development. p53 is the most frequently mutated gene in cancer $(50 \%)$ and loss of p53 activity is considered to be ubiquitous to all cancers. Recent publications may have a profound impact on our understanding of p53 tumour suppressor activity. p63, p73 and $p 53$ genes have a dual gene structure conserved in drosophila, zebrafish and man. They encode for multiple p63, p73 or p53 proteins containing different protein domains (isoforms) due to multiple splicing, alternative promoter and alternative initiation of translation. In this review, we describe the different isoforms of p63, p73, p53 and their roles in development and cancer. The changes in the interactions between p53, p63 and p73 isoforms are likely to be fundamental to our understanding in the transition between normal cell cycling and the onset of tumour formation.

Cell Death and Differentiation (2006) 13, 962-972.

doi:10.1038/sj.cdd.4401914; published online 7 April 2006
\end{abstract}

Keywords: splice; promoter; drosophila; zebrafish; development; cancer

Abbreviations: bp, base pair; p53RE, p53 responsive element; TA, TransActivation Domain of p53/p63/p73; AML, Acute Myeloid Leukemia; FLp53, full-length p53; MEF, Mouse embryonic fibroblast

\section{Introduction}

p53 was discovered in 1979 as a protein interacting with the oncogenic T antigen from SV40 virus. ${ }^{1-5}$ p53 protein is the product of a pivotal tumor-suppressor gene whose inactivation by mutation or interaction with viral or overexpressed cellular proteins occurs in almost all cancers. ${ }^{6}$ The $\mathrm{p} 53$ protein integrates multiple cellular stress signals assessing cellular damages to trigger either cell-cycle arrest or programmed cell death (apoptosis). ${ }^{7}$ These effects are predominantly due to p53's ability to bind DNA through p53-responsive element $(\mathrm{p} 53 \mathrm{RE})^{8,9}$ and regulate the transcription of genes involved in these processes, such as $p 21^{10}$ (cell cycle arrest), Puma ${ }^{11}$ or Scotin $^{12}$ (apoptosis). Thereby, p53 prevents proliferation of genetically abnormal cells and thus cancer formation.

Two p53-related genes, $p 63$ and $p 73$, were identified in $1997 . .^{13,14}$ The high level of sequence similarity between $p 63$, p73 and p53 proteins, particularly in the DNA binding domain, allows p63 and p73 to transactivate p53-responsive genes causing cell cycle arrest and apoptosis. Therefore, $p 63, p 73$ and $p 53$ genes form a family of transcription factor. However, they are not functionally entirely redundant and the primary role of each p53 family member - as determined by transgenetic knockout mice - illustrates that each protein has its own unique functions.

We recently published that the $p 53$ gene family has a dual gene structure conserved from drosophila to man. ${ }^{15}$ Like most of the genes in the human genome, ${ }^{16}$ p53 gene family members express multiple mRNA variants due to multiple splicing and alternative promoters. Hence, $p 53$ gene family members express different forms of p53 protein containing different domain of the protein (isoforms). In this review, we will summarise the different isoforms of p63, p73 and p53 expressed in human, mouse and drosophila.

\section{p63}

The mouse $p 63$ gene is composed of 15 exons spanning over 208000 bp (GenBank Accession Number: AF533892) on chromosome 16, while the human $p 63$ gene is composed of 15 exons, spanning over 270000 bp on chromosome 3q27 (GenBank Accession Number: AC078809 (exon 1), AC117486 and AC063939) (for a review see McKeon ${ }^{17}$ ). The discovery of an internal promoter within the p53 family was first made with $p 63 .^{13}$ The human and mouse $p 63$ genes express at least three alternatively spliced C-terminal isoforms $(\alpha, \beta, \gamma)$, and can be transcribed from an alternative promoter located in the intron 3 (Figure 1a). The transactivating isoforms (TAp63) are generated by the activity of the promoter upstream of exon 1 while the alternative promoter in intron 3 leads to the expression of amino terminally truncated isoforms $(\Delta \mathrm{Np} 63)$ lacking the transactivation domain. Altogether, the $\mathrm{p} 63$ gene expresses at least six mRNA variants which encode for six different p63 protein isoforms (TAp63 $\alpha$, TAp63 $\beta$, TAp63 $\gamma, \Delta \mathrm{Np} 63 \alpha, \Delta \mathrm{Np} 63 \beta$, and $\Delta \mathrm{Np63} \gamma$ ) (Figure 1b).

The TAp63 isoforms are able to bind to DNA through p53RE and activate transcription of target genes. Such activation can induce cell cycle arrest or apoptosis, which has lead to this subset of p63 isoforms being described as 'p53-like'. Recent studies indicate that p63 proteins can bind DNA through response element (p63RE) slightly different to p53RE 
a Human p63 gene structure

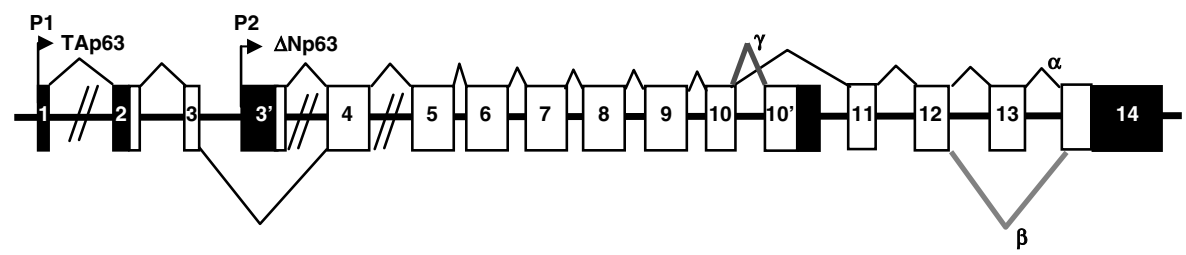

b 663 protein isoforms

\begin{tabular}{|c|c|c|c|c|c|c|c|c|}
\hline & \multicolumn{2}{|c|}{ TA } & DNA-Binding domain & Oligo & \multicolumn{4}{|c|}{ C-terminal domains } \\
\hline TAp63 $\alpha$ & 2 & 3 & & 10 & 11 & 12 & 13 & 14 \\
\hline TAp63 $\beta$ & 2 & 3 & & 10 & 11 & 12 & 14 & \\
\hline TAp63 $\gamma$ & 2 & 3 & & 10 & 10 & & & \\
\hline
\end{tabular}

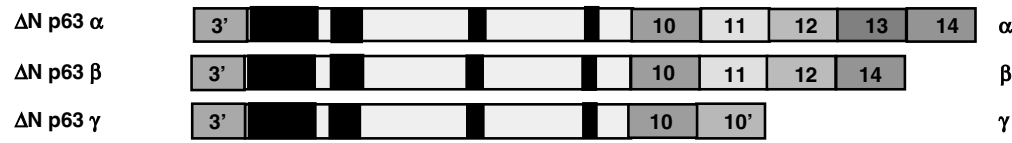

Figure 1 Human p63. (a) Schema of the human p63 gene structure: alternative splicing $(\alpha, \beta$ and $\gamma)$ and alternative promoters (P1 and P2) are indicated. (b) p63 protein isoforms: TAp63 proteins encoded from promoter P1 contain the conserved N-terminal domain (Fxx $\psi \mathrm{W}$ ) of transactivation (TA). $\Delta$ Np63 proteins encoded from promoter P2 are amino-truncated proteins containing an $\mathrm{N}$-terminal domain different from TAp63 proteins. Numbers indicate the exons encoding p63 protein isoforms

conferring responsiveness to p63 but not p53 proteins. ${ }^{18,19}$ The $\triangle \mathrm{Np63}$ isoforms can bind DNA through p53RE and can exert dominant-negative effects over p53, p73 and p63 activities by either competing for DNA binding sites or by direct protein interaction (for a review Benard et $\mathrm{a}^{20}$ ). $\Delta \mathrm{Np} 63$ isoforms were also shown to directly activate specific gene targets not induced by TA isoforms. ${ }^{21,22}$ By expressing TAp63 and $\Delta \mathrm{Np} 63$ isoforms, $\mathrm{p} 63$ has the ability to regulate a number of genes with diverse roles and possesses opposing regulatory effects depending on the form used.

So far, there have been limited data concerning the expression patterns of individual p63 proteins, due to a lack of antibodies that distinguish between the different isoforms $(\alpha, \beta, \gamma) . \Delta$ Np63 isoforms are abundantly expressed in the progenitor cell layers of skin, breast and prostate, while TAp63 proteins are barely detectable, indicating a switch in expression of p63 isoforms during normal cellular differentiation (for a review, see McKeon ${ }^{17}$ ). In squamous carcinomas, $\Delta$ Np63 is the main isoform expressed, and it was thought to play an important role in keeping the cells in a stem cell-like state continually allowing proliferation and thus promoting tumour growth. However, a recent study challenges this interpretation. Koster et al. ${ }^{23}$ demonstrate that TAp63 isoforms are the first to be expressed during embryogenesis and are required for initiation of epithelial stratification. In addition, TAp63 isoforms inhibit terminal differentiation, suggesting that TAp63 isoforms must be counterbalanced by $\Delta$ Np63 isoforms to allow cells to respond to signals required for maturation of embryonic epidermis and to differentiate.

\section{p63 and cancer}

The role of p63 in cancer is still unclear (for a review, see Mills $\left.{ }^{24}\right)$. Some $\mathrm{p} 63+1-$ mice are cancer-prone ${ }^{25}$ while other genetic background $\mathrm{p} 63+/$ - mice show premature aging but no cancer. ${ }^{26}$
In humans, the p63 gene can be frequently amplified in squamous cells in lung ${ }^{27}$ and cervical carcinomas. ${ }^{28}$ TAp63 proteins are expressed in the nuclei of a subpopulation of lymphoid cells and in most malignant lymphomas, whereas $\Delta$ Np63 proteins are not expressed. ${ }^{29,30}$

\section{Biological activities of the p63 isoforms}

Genetic experiments on mice have shown that p63 is essential for epidermal morphogenesis and limb development. p63-null animals do not survive beyond a few days after birth, show craniofacial malformations, limb truncations and fail to develop skin and other epithelial tissues. ${ }^{13,31}$ Although less severe than the phenotype observed with the knockout mice, germ line mutations of $\mathrm{p} 63$ are found in humans ${ }^{32}$ and cause six rare autosomal dominant developmental diseases which include

1. Ectrodactyly Ectodermal dysplasia-Clefting syndrome (EEC). EEC syndrome has three major features: Ectrodactyly-(also known as lobster-claw anomaly of the hands and feet), Ectodermal dysplasia (developmental defects of ectodermally derived structures that include hair, teeth, nails and sweat glands) and Clefting (cleft lip with or without cleft palate).

2. Acro-dermato-ungual-lacrimal-tooth malformations (ADULT). ADULT syndrome differs from EEC syndrome by the absence of facial clefting.

3. Limb-Mammary Syndrome (LMS). LMS patients suffer from split-hand/foot malformation, mammary gland and nipple hypoplasia and isolated cleft palate, but do not suffer from ectodermal dysplasia.

4. Hay-Wells syndrome, also named AEC syndrome for Ankyloblepharon (partial or complete fusion of eyelids) and Ectodermal dysplasia-Clefting. AEC patients have minimal or no limb anomaly at the difference of EEC patients. 
5. Split-hand/foot malformations (SHFM). Patients have median clefts of the hands and feet but no other features of EEC syndrome. p63 germ line mutations probably account for no more than $10 \%$ of SHFM.

6. Rapp-Hodgkin Syndrome. Patients suffer from ectodermal dysplasia, cleft lip and palate, deformed ears and genitourinary abnormalities.

Different germ-line mutations have been identified throughout the p63 gene for these syndromes. However, EEC ${ }^{33}$ and ADULT $^{34}$ syndromes (ectrodactyly) result from missense mutations in the DNA-binding domain of p63 affecting all p63 isoforms, whereas AEC (absence of ectrodactyly) ${ }^{35}$ are caused by missense mutations in exon 13 mutating only TAp63 $\alpha$ and $\Delta \mathrm{Np} 63 \alpha$ isoforms. This strongly suggests that TAp63 $\alpha$ and $\Delta \mathrm{Np} 63 \alpha$ isoforms have distinct biological activities to the other p63 isoforms. TAp63 $\alpha$ and $\Delta \mathrm{Np} 63 \alpha$ isoforms are necessary to normal ectodermal development of specific organs. This suggests that each p63 isoform has specific biological and biochemical activities. Future studies will probably aim to establish a phenotype-genotype correlation for p63 gene mutations and p63 isoform expression.

\section{p73}

The mouse and human $p 73$ genes are composed of 15 exons spanning over $80000 \mathrm{bp}$ (GenBank Accession Number: AL806525) on chromosome 4 and on chromosome 1p36.3 (GenBank Accession Number: AL136528), respectively. The p73 gene expresses at least seven alternatively spliced Cterminal isoforms $(\alpha, \beta, \gamma, \delta, \varepsilon, \zeta$ and $\eta)$ (for a review, see Moll and Slade ${ }^{36}$ and Melino et $a^{\beta 7}$ ) and at least four alternatively spliced N-terminal isoforms initiated at different ATG. ${ }^{38}$ Like $p 63$, the $p 73$ gene can be transcribed from an alternative promoter located in the intron 3 (Figure 2a). The transactivating isoforms are generated by the activity of the promoter upstream of exon 1 while the alternative promoter in intron 3 leads to the expression of amino terminally truncated isoforms $(\Delta \mathrm{Np} 73)$ lacking the transactivation domain. Altogether, the p73 gene expresses at least 35 mRNA variants, which can encode theoretically 29 different p73 protein isoforms (Figure 2b). So far, 14 different p73 protein isoforms have been described. In contrast to p63, p73 isoforms can be initiated from different ATG and contain different part of the Nterminal domain, suggesting that they can have distinct protein interactions and specific activities (Figure $2 b$ ). It should be noted that the total number of p73 isoforms is probably not definitive as all alternative splicing combinations have not been explored. Moreover, to our knowledge, it has not been shown which form of $p 73$ protein is expressed from the $\triangle N^{\prime}$ p73 mRNA. As this variant contains the three first exons of TAp73, it is very likely that translation is initiated from the first ATG located in exon 2 leading to expression of a short p73 protein composed only of the $\mathrm{N}$-terminal domain of p73 as exon $3^{\prime}$ contains a stop codon.

The TAp73 isoforms are able to bind specifically to DNA through p53RE and activate transcription of target genes. Like p53, such activation can induce cell cycle arrest or apoptosis. The $\Delta \mathrm{N}$ isoforms bind DNA through p53RE and can exert dominant-negative effects over p53, p73 and p63 activities (for a review, see Benard et $a^{20}$ and Melino et $a{ }^{37}$ ). $\Delta \mathrm{Np} 73$ isoforms were also shown to directly activate specific gene targets not induced by TA isoforms. ${ }^{39}$ The $\Delta$ Np73 isoforms can act in a dominant-negative manner by either competing for DNA binding sites or by direct protein interaction, and as a result show antiapoptotic characteristics. Recent studies indicate that p73 proteins can bind DNA through response element slightly different to $\mathrm{p} 53 \mathrm{RE}$ conferring responsiveness to $\mathrm{p} 73$ but not $\mathrm{p} 53$ proteins. ${ }^{19}$

\section{Biological activities of the p73 isoforms}

So far, there have been limited data concerning the expression patterns of individual p73 proteins, due to a lack of antibodies that distinguish between the different isoforms. The p73 gene is expressed in all normal tissues studied to date, although expression is at very low level.

The p73 variants have been shown in mouse and cell culture studies to have distinct roles. Rather strikingly, the predominant form of $p 73$ in the developing mouse brain is in fact $\Delta \mathrm{Np} 73$ and not the TA proteins. ${ }^{40}$ The $\Delta \mathrm{Np} 73$ isoforms are highly expressed in the developing mouse brain. During the normal 'sculpting' of the developing mouse neuronal system, $\Delta \mathrm{Np} 73$ isoforms are needed to counteract p53mediated neuronal death. The removal of the nerve growth factor (NGF) leads to both an induction of p53-mediated cell death and a decrease of $\Delta N p 73$. The importance of $\Delta N p 73$ in this system is demonstrated by the fact that increasing $\Delta N p 73$ levels alone rescues the sympathetic neurones from death. ${ }^{40}$ The $p 73$ gene is also developmentally regulated during kidney organogenesis. The spatiotemporal switch from $\Delta \mathrm{Np} 73$ to TAp73 may play an important role in the terminal differentiation program of the developing nephron. ${ }^{41}$ Although the $\Delta \mathrm{N}$ isoforms are generally thought to be dominant-negative in their activity, $\Delta \mathrm{Np} 73 \beta$ and $\Delta \mathrm{Np} 73 \gamma$ have in fact been found to be active in transactivation and growth suppression in cell culture models, while $\Delta \mathrm{Np} 73 \alpha$ is not. ${ }^{39}$

The C-terminally spliced p73 variants have also been found to have different transcriptional activity. ${ }^{42}$ The expression of certain C-terminal variants as opposed to others has been correlated with normal myeloid differentiation. p73 $\alpha$ and p73 $\beta$ are linked with normal myeloid differentiation, while $p 73 \gamma$, $\mathrm{p} 73 \delta, \mathrm{p} 73 \varepsilon$ and $\mathrm{p} 73 \theta$ are linked with leukaemic blasts, with p73e being specific for leukaemic blast cells. ${ }^{43}$ Further evidence for a role in cellular differentiation suggests that TAp73 $\gamma$ and $\operatorname{TAp} 73 \delta$ may be involved in the terminal differentiation of human skin keratinocytes. ${ }^{44}$

Mice, functionally deficient for all p73 isoforms, exhibited profound defects, including hippocampal dysgenesis, hydrocephalus, chronic infections and inflammation, as well as abnormalities in pheromone sensory pathways, however, did not show any increase susceptibility to cancer. ${ }^{45}$ The p73deficient male mice lacked both interest in sexually mature females and aggressive responses to other males. p73-/male and female mice were reproductively deficient. No structural abnormalities in the reproductive organs of either male or female p73-/- mice were observed, but the highest level of p73 RNA in the mouse was found in the neuroepithelium of both the embryonic and adult vomeronasal organ, an accessory olfactory structure involved in 
a Human p73 gene structure

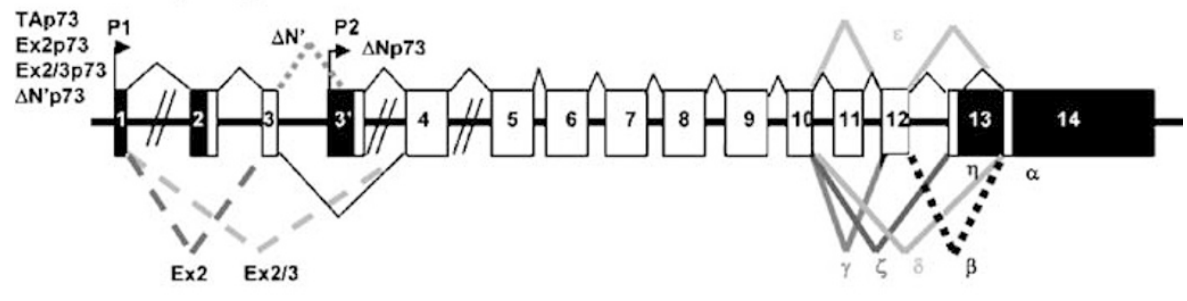

b

\begin{tabular}{|c|c|c|c|c|c|c|c|c|}
\hline p73 protein isoforn & & & DNA-Binding domain & ligo & & $\min$ & don & \\
\hline TAp73 $\alpha$ & 2 & 3 & & 10 & 11 & 12 & 13 & 14 \\
\hline TAp73 $\beta$ & 2 & 3 & & 10 & 11 & 12 & 14 & \\
\hline TAp73y & 2 & 3 & & 10 & 12 & 13 & 14 & \\
\hline TAp73 $\delta$ & 2 & 3 & & $\overline{10}$ & 14 & & & \\
\hline TAp73 $\varepsilon$ & 2 & 3 & & 10 & 12 & 14 & & \\
\hline TAp73 $\zeta$ & 2 & 3 & . & 10 & 13 & 14 & & \\
\hline TAp73 $\eta$ & 2 & 3 & & 10 & 11 & 12 & & \\
\hline
\end{tabular}

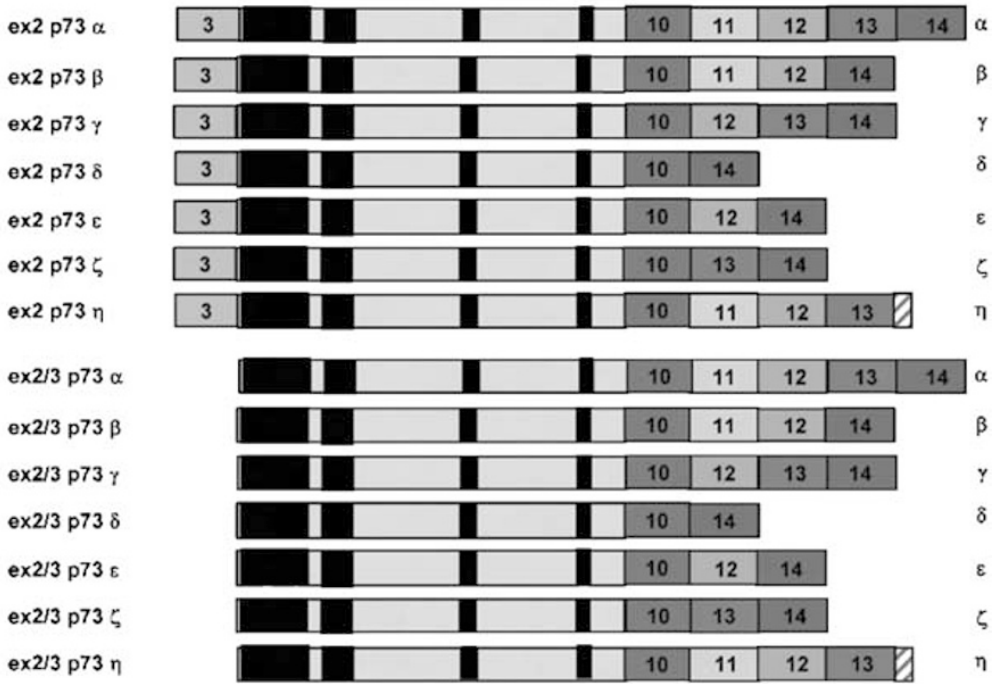

\begin{tabular}{ll|l|l|l|l}
$\Delta N$ & p 73 & 2 & 3 & 3 & or
\end{tabular}

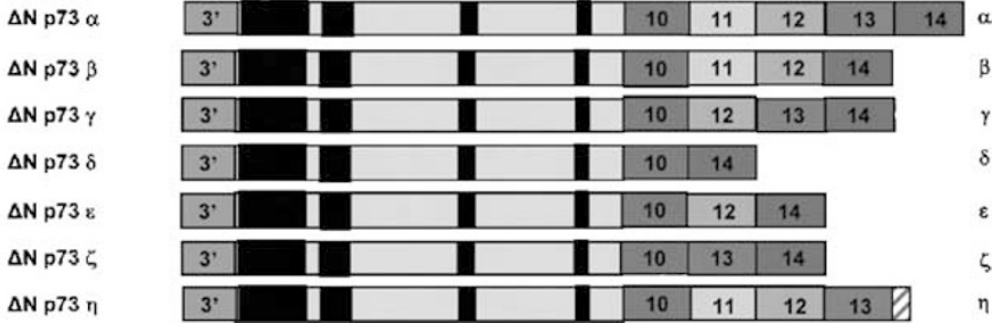

Figure 2 Human p73. (a) Schema of the human $p 73$ gene structure: Alternative splicing $(\alpha, \beta, \gamma, \zeta, \delta, \varepsilon, \eta)$ and alternative promoters (P1 and P2) are indicated. (b) p73 protein isoforms: TAp73 proteins encoded from promoter P1 contain the conserved $\mathrm{N}$-terminal domain (Fxx $\psi \mathrm{W})$ of transactivation (TA). Ex2p73 proteins are due to alternative splicing of exon 2. They have lost the conserved N-terminal domain ( $\mathrm{Fxx} \psi \mathrm{W}$ ) of transactivation (TA) but still contain part of the transactivation domain (Exon 3). Ex2/3p73 proteins are due to alternative splicing of exons 2 and 3. They have entirely lost the transactivation domain (TA) and are initiated from exon 4 . To our knowledge, the protein encoded by $\triangle N^{\prime} p 73$ mRNA has not been described. $\Delta N^{\prime} p 73$ variant is often overexpressed at the mRNA level in tumours. $\Delta N^{\prime} p 73$ is due to alternative splicing of exon $3^{\prime}$ contained in intron 3 . Theoretically, $\Delta \mathrm{N}^{\prime} \mathrm{p} 73 \mathrm{mRNA}$ would encode either for a short p 73 protein or p73 protein isoforms identical to $\Delta N p 73$. $\Delta N^{\prime}$ p73 mRNA contains the normal initiation site of translation in exon 2 (ATG in perfect kozak sequence) and a stop codon in exon $3^{\prime}$. Therefore it could encode for a short 73 protein composed only of the transactivation domain ( $F x x \psi W$ ). It is possible that translation of $\triangle N^{\prime} p 73 \mathrm{mRNA}$ is initiated from the third ATG available present in exon $3^{\prime}$ and leading to $\mathrm{p} 73$ protein identical to $\Delta \mathrm{Np} 73$ protein isoforms. $\Delta \mathrm{Np} 73$ proteins encoded from promoter $\mathrm{P} 2$ are amino-truncated proteins containing an $\mathrm{N}$ terminal domain different from TAp73 proteins. Numbers indicate the exons encoding p73 protein isoforms 
pheromone detection. These results suggested that additional defects of sensory or hormonal pathways may contribute to the reproductive and behavioural phenotypes of p73deficient mice. ${ }^{45}$

Contrary to p63, no human genetic disorders have been associated yet with germ line mutation of the $p 73$ gene.

\section{p73 and cancer}

The $p 73$ gene, though mutated rarely, does show a significant incidence of loss of heterozygosity in a number of different cancers. p73 isoform is differentially expressed in a number of tumours including: bladder, breast, lung, neuroblastoma and hepatocellular carcinoma, compared to the tissue of origin (for review see Moll and Slade ${ }^{36}$ and Melino et $a^{37}$ ). However, RTPCR was carried out in most of these studies so the levels of p73 protein and the isoforms were not assessed. As with p63, the $\mathrm{N}$-terminally truncated $\mathrm{p} 73$ proteins $-\Delta \mathrm{Np} 73$, ex2p73 and ex2/3p73, which all have antiapoptotic functions - have been found to be upregulated in many cancers. Moreover, the ex2p73 appears to be a cancer-specific isoform given that it is not expressed in normal tissues, but has been found in ovarian, vulval and neuroblatoma cancers. ${ }^{46,47}$ The overexpression of $\Delta \mathrm{Np} 73$ has been shown to be a poor prognostic marker in patients suffering from neuroblastoma. In a study of 52 patients, those that were $\Delta \mathrm{Np} 73$-negative had an overall survival rate of $\sim 80 \%$, compared to the $\Delta \mathrm{Np} 73$-positive patients, all of whom died. This suggests that $\Delta \mathrm{Np} 73$ function is important for tumour survival, possibly by inhibiting the apoptotic activities of p53 and TAp73. ${ }^{48}$

\section{p53}

The mouse $p 53$ gene is composed of $12000 \mathrm{bp}$, spanning over 11 exons (GenBank Accession Number: NC_000077) on chromosome 11, while the human p53 gene is composed of 19200 bp, spanning over 11 exons (GenBank Accession Number: NC_000017) on chromosome 17p13.1. Until recently, the p53 gene structure was much simpler. Only one promoter and three mRNA splice variants were described for p53, which would encode respectively full-length p53 (FLp53), p53i9 $9^{49,50}$ and $\Delta 40$ p53. ${ }^{51,52}$ The variant p53i9 is encoded by alternative splicing of the intron 9, a p53 protein isoform truncated of the last 60 amino acids of p53, defective in transcriptional activity. $\Delta 40 p 53$ (also named p47 or $\Delta N p 53$ ) is an amino-terminally truncated p53 isoform deleted of the first 40 amino-acids. $\Delta 40$ p53 protein can be generated either by an alternative splicing of the intron 2 or by alternative initiation of translation. The $\Delta 40 \mathrm{p} 53$ protein still contains part of the p53 transactivation domain and can activate gene expression after transfection through a second transactivation domain located between amino-acid 43 and $63 .{ }^{53} \Delta 40 p 53$ can also act after transfection, in a dominant-negative manner towards WTp53 inhibiting both p53 transcriptional activity and p53-mediated apoptosis. $^{52} \Delta 40$ p53 can modify p53 cell localisation and inhibits p53 degradation by MDM2 ${ }^{52}$ (for a review, see Mills ${ }^{54}$ ).

However, this human p53 gene structure is not consistent with our current understanding of the evolution of the p53 gene family. Mammalian genomes contain three members of the $p 53$ family while only one member has been identified in invertebrates, suggesting that the mammalian p53 family members are derived from the triplication of one ancestral gene. We recently published that human $p 53$ gene has indeed a dual gene structure similar to $p 73$ and $p 63$ genes (Figure 3a). ${ }^{15}$ We identified that $p 53$ gene transcription can be initiated from two distinct sites upstream of exon 1 and from an internal promoter located in intron 4. The alternative promoter leads to the expression of an amino-terminally truncated p53 protein initiated at codon $133(\Delta 133 p 53)$. The intron 9 can be alternatively spliced to produce three isoforms $\mathrm{p} 53, \mathrm{p} 53 \beta$ and $\mathrm{p} 53 \gamma$, where the $\mathrm{p} 53 \beta$ and $\mathrm{p} 53 \gamma$ isoforms lack the oligomerisation domain. Therefore, the human p53 gene can encode at least nine different p53 protein isoforms, which we named accordingly to p63/p73 nomenclature $\mathrm{p} 53, \mathrm{p} 53 \beta, \mathrm{p} 53 \gamma, \Delta 133 \mathrm{p} 53, \Delta 133 \mathrm{p} 53 \beta$ and $\Delta 133 p 53 \gamma$ due to alternative splicing of the intron 9 and usage of the alternative promoter in intron 4 , and also $\Delta 40 p 53$, $\Delta 40 \mathrm{p} 53 \beta, \Delta 40 \mathrm{p} 53 \gamma$ due to alternative splicing of the intron 9 and alternative initiation of translation or alternative splicing of the intron $2^{52}$ (Figure $3 b$ ). p53 variant mRNA are expressed in several normal human tissues in a tissuedependent manner, suggesting that the internal promoter and the alternative splicing of p53 can be regulated. p5319 is identical to $\mathrm{p} 53 \beta$.

It has recently been reported that alternative splicing of the exon 7 of p53 leads to a p53 isoform deleted of the conserved box $\mathrm{V}$ in the DNA binding domain $(\Delta \mathrm{p} 53) .{ }^{55}$ This splicing is quite remarkable as it is not consistent with any known rules of splicing, which are strictly conserved through all eukaryotes. Despite all our efforts, we could not detect by PCR, the variant $\Delta$ p53 in 21 normal human tissue analysed (brain, heart, lung, liver, colon, bone marrow, thymus, spleen, testis, prostate, uterus, skeletal muscle, stomach, kidney, placenta, fetal brain, fetal liver, salivary gland, adrenal gland, thyroid, breast) nor in tumours (106 breast tumours, 80 AML, 40 head-neck tumours). This could be because of tissue specific expression. One would need to wait for a specific antibody against $\Delta \mathrm{p} 53$ to determine its endogenous protein expression in tissue and tumours.

We have shown that endogenous p53 isoforms are expressed at the protein level but cannot be identified by a commonly available p53 antibody. It is only by raising a specific anti-p53 $\beta$ antibody that we demonstrated expression of the endogenous $\mathrm{p} 53 \beta$ and $\Delta 133 \mathrm{p} 53 \beta$ protein isoforms. This implies that $p 53 \gamma, \Delta 133 p 53 \gamma$ and $\Delta 133 p 53$ are expressed at the protein level. We are currently raising new antibodies specific of $p 53 \gamma$ and $\Delta 133 p 53$ proteins.

p53 isoforms can have distinct biochemical activities. p53 $\beta$ binds preferentially the p53-responsive promoters p21 and Bax rather than Mdm2, while p53 binds preferentially to Mdm2 and $\mathrm{p} 21$ rather than Bax promoters. $\mathrm{p} 53 \beta$ can form a protein complex with p53 and can specifically enhance p53 transcriptional activity at the Bax promoter, while it has no effect on the p21 promoter. Co-transfection of p53 with p53 $\beta$ increases slightly p53-mediated apoptosis, while co-transfection of p53 with $\Delta 133 p 53$ strongly inhibits p53-mediated apoptosis in a dose dependent manner. This suggests that a subtle and complex balance between the different p53 isoforms and p53 could regulate cellular fate outcome in response to p53 activation. $^{15}$ 
a Human p53 gene structure

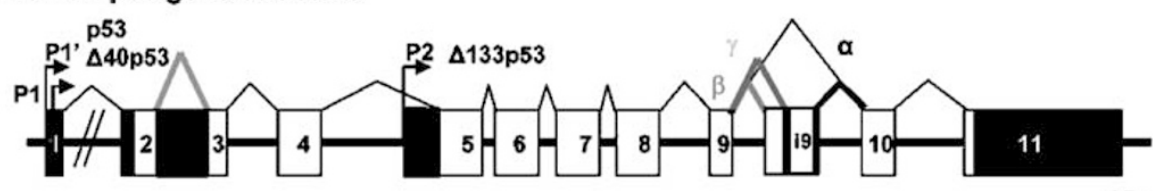

15 mRNA

9 proteins

\section{b Putative p53 protein isoforms}

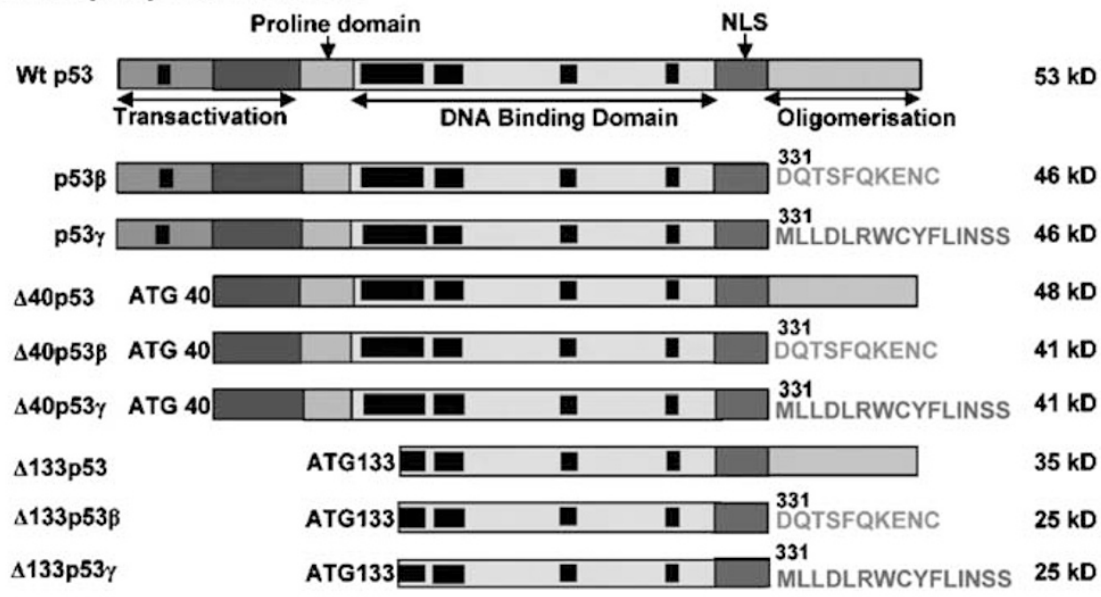

C Endogenous p53 by 2D gels (MCF7)

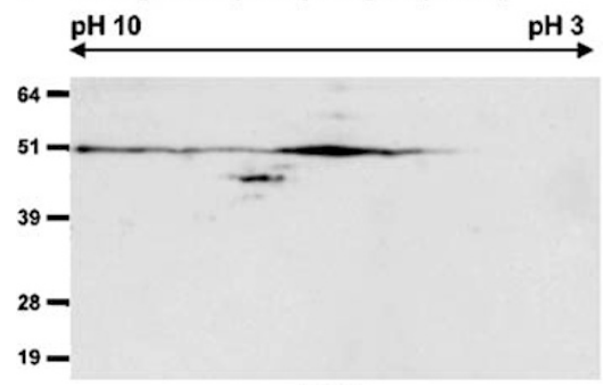

DO-1

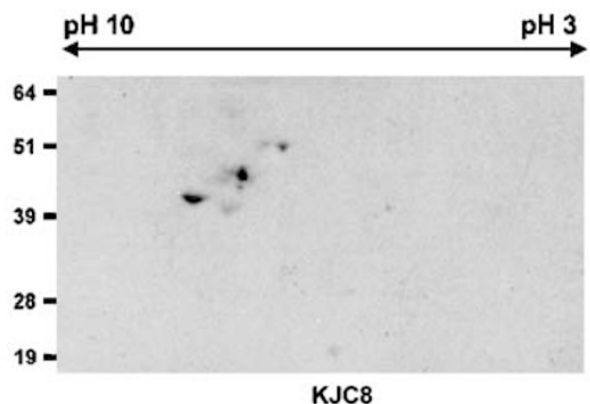

Figure 3 Human p53. (a) Schema of the human p53 gene structure: alternative splicing $(\alpha, \beta, \gamma)$ and alternative promoters (P1, P1' and P2) are indicated. (b) p53 protein isoforms: $\mathrm{p} 53, \mathrm{p} 53 \beta$ and $\mathrm{p} 53 \gamma$ proteins encoded from $\mathrm{P} 1$ or $\mathrm{P} 1^{\prime}$ promoters contain the conserved $\mathrm{N}$-terminal domain (Fxx $\psi \mathrm{W}$ ) of transactivation (TA). $\Delta 133 \mathrm{p} 53$ isoforms encoded from promoter $\mathrm{P} 2$ are amino-truncated proteins deleted of the entire transactivation domain and deleted of part of the DNA binding domain. Translation is initiated at ATG-133. $\triangle 40$ p53 protein isoforms encoded from $\mathrm{P} 1$ or $\mathrm{P} 1^{\prime}$ promoters are amino-truncated proteins due to alternative splicing of exon 2 and/or alternative initiation of translation at ATG-40). $\triangle 40 \mathrm{p} 53$ protein isoform have lost the conserved $\mathrm{N}$-terminal domain of transactivation (Fxx $\psi \mathrm{W}$ ) but still contain part of the transactivation domain. (c) p53 proteins from MCF7 cell lines by two-dimensional gel electrophoresis and Western blot. p53 is revealed by mouse monoclonal DO-1 antibody and $p 53 \beta$ is revealed by peptide-affinity purified rabbit polyclonal KJC8 antibody. MCF7 cells were grown under standard cell culture conditions

Although the extent of p53 isoform expression in cancers has yet to be fully investigated, our preliminary analysis indicates that $\mathrm{p} 53 \beta$ expression is frequently lost and $\Delta 133 p 53$ is frequently overexpressed on breast tumours, while only $25 \%$ of breast tumours express mutant p53. The abnormal expression of p53 isoform could disrupt the p53 response, making the cells more susceptible to further genetic damage and, therefore, tumour progression. The differential expression of p53 isoforms in human tumours may provide some explanation to the difficulties in many clinical studies to link p53 status to the biological properties and drug sensitivity of human cancers.

In order to clarify the relevance of the p53 isoforms in cancer, it will be essential to investigate their expression in a wider series of human tumours.

\section{Conservation through evolution of the $p 53$ gene structure}

All the $p 53$ gene family members contain an internal promoter suggesting that they derive from the triplication of an ancestral gene. However, only one transcript has been described for drosophila $p 53$ gene (dp53). ${ }^{56,57}$ By amplifying capped transcripts, we identified two additional transcripts containing two novel exons ( $A$ and $B$ ) located upstream of the previously identified $d p 53$ gene. ${ }^{15}$ One mRNA encodes for a drosophila p53 protein of 495 aa (110 aa longer than the dp53 initially published) with a longer $\mathrm{N}$-terminal domain containing the conserved transactivation domain Fxx $\psi \mathrm{W}$. The second mRNA contains still, the intron B and encodes for a short drosophila p53 protein of 110 aa, containing only the 
$\mathrm{N}$-terminal domain. Therefore, the promoter that had been characterised in previous studies was in fact, an internal promoter. This indicates that the internal promoter is conserved among the $p 53$ gene family and through evolution, from drosophila to man. It strongly suggests that the internal promoter plays an essential role in the multiple activities of the p53 family members.

Consistent with this hypothesis, $\Delta 113 p 53$, the homologue of human $\Delta 133 p 53$ in zebrafish, has been identified and characterised by genetic experiments. ${ }^{58}$ The authors determined that $\Delta 113 p 53$ expression is regulated by def (digestive-organ expansion factor) gene. A loss-of-function mutation in def confers hypoplastic digestive organs and selectively upregulates the expression of $\Delta 113 p 53$ but not p53, resulting in compromised organ growth in def mutant Zebrafish.

Evidence to date suggests that there may be important differences between the p53 isoforms expressed in mouse and human cells. It was described that the mouse p53 gene contains one promoter and transcribes only two mRNA variants with an alternative splicing of the intron 10 encoding for a p53 protein (p53AS) containing still the oligomerisation domain, but missing the last 30 amino acids of full-length $\mathrm{p} 53{ }^{59}$ while human $\mathrm{p} 53 \beta$ and $\mathrm{p} 53 \gamma$ have lost the entire oligomerisation domain. Mouse p53AS isoform is constitu- tively active for sequence-specific DNA binding and can transactivate p53 target genes but inhibits full-length p53 mediated apoptosis. ${ }^{60}$ p53AS is induced by actinomycin D, while human p53 protein isoforms are not accumulated in tumour derived cell lines in response to actinomycin D. ${ }^{61}$ However, the p53AS isoform appears to be mouse-specific as it has not been found in rat or human. ${ }^{62,63}$ These findings imply that the generation of functionally different forms of p53 by alternative splicing of p53 transcripts is a species-specific event, possibly indicating species-specific mechanisms for regulating $\mathrm{p} 53$ activities. Up-to-date, no alternative promoter has been reported for mouse $p 53$ gene. Our preliminary data indicate that the mouse p53 gene contains an alternative promoter in intron 4 like drosophila, human and zebrafish p53 genes.

\section{Biological activities of p53 and its isoforms}

Mice, functionally deficient for all p53 isoforms (knock-out p53 or $p 53^{-1-}$ ), are developmentally normal but are prone to the spontaneous development of a wide variety of neoplasms by 6 months of age. ${ }^{64}$ In different genetic backgrounds, $553^{-/-}$ mice are cancer-prone but also show abnormal development.

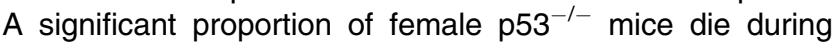
embryogenesis, in the period between birth and weaning,

Figure 4 Expression and biological activities of p53 protein isoforms. (a) Immunoprecipitation of endogenous p53 $\beta$ and $\Delta 133 p 53 \beta$ protein isoforms from U2OS protein extract. Protein from U2OS and H1299 cells cultured under standard cell culture conditions were extracted and treated for immunoprecipitation as described

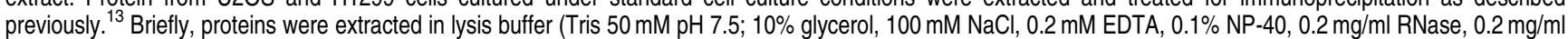
Dnase, $1 \mathrm{mg} / \mathrm{ml}$ protease inhibitor (Roche complete Pefabloc)). In total, $100 \mu \mathrm{g}$ total protein extract was incubated overnight at $4 \mathrm{C}$ with $5 \mu \mathrm{g}$ of peptide $\beta$-affinity purified rabbit polyclonal antibodies KJC8 or KJC40 or pre-immune sera as a control. p53 content was revealed after western-blot using sheep polyclonal antibody (SP) antihuman $553 .{ }^{13} 10 \%$ of the input was loaded as a control. KJC8 and KJC40 rabbit polyclonal antibodies were raised against the same peptide- $\beta$. KJC8 and KJC40 antibodies immunoprecipitate endogenous $p 53 \beta$ and $\Delta 133 p 53 \beta$ in U2OS cell protein extract. Only KJC8 can co-immunoprecipitate p53 with p53 $\beta$ and $\Delta 133 p 53 \beta$, probably because KJC8 and KJC40 recognise different amino acids of the peptide- $\beta$ (TLQDQTSFQKENC). The secondary HRP-anti-sheep-antibody crossreacts with light chain of rabbit $\operatorname{lgG}(\operatorname{lgG})$. (b) 293 cells express several p53 isoform proteins. 293 cells, expressing endogenous WT p53, were seeded at $80 \%$ confluency and cultured for $24 \mathrm{~h}$ under standard cell culture conditions. Proteins were extracted and analysed (10 $\mu \mathrm{g}$ protein) by Western blot using a panel of anti-human p53 antibodies. The sheep polyclonal (SP) and rabbit polyclonal (CM1) antibodies were raised against full-length human p53. The mouse monoclonal DO-1 is specific of the $\mathrm{N}$-terminal domain (amino-acid 19-25) of human p53. The rabbit polyclonal p53Ser15 antibody is specific for p53 proteins phosphorylated on Ser 15 at the N-terminal end. Rabbit polyclonal KJC8 antibody is specific of $\mathrm{p} 53 \beta, \Delta 40 \mathrm{p} 53 \beta$ and $\Delta 133 \mathrm{p} 53 \beta$. The secondary antibody HRP-anti-rabbit lgG was used as a control (ctrl). The marker $(\mathrm{m})$ is indicated in $\mathrm{kDa}$. Bands a and b contain full-length p53. Bands $\mathrm{c}$ and $\mathrm{d}$ contain p53 3 . Bands e and $\mathrm{f}$ contain amino-truncated p53 protein since DO-1 does not reveal them. The rabbit polyclonal p53Ser15 antibody reveals that p53 protein isoforms can be phosphorylated on Ser15. (c) p53 protein isoforms expression in several cell lines. Protein from different cell lines cultured under standard cell culture conditions were extracted in RIPA buffer $(0.1 \%$ SDS, $1 \%$ NP- $40,0.5 \%$ DCA, $1 \mathrm{mM}$ EDTA, $0.2 \mathrm{mg} / \mathrm{ml}$ RNase, $0.2 \mathrm{mg} / \mathrm{ml}$ Dnase, $1 \mathrm{mg} / \mathrm{ml}$ protease inhibitor (Roche complete Pefabloc)) and analysed by Western blot as described. ${ }^{13} \mathrm{p} 53$ protein isoforms were detected using rabbit polyclonal CM1, while $\mathrm{p} 53 \beta$ protein isoforms were revealed using peptide-affinity purified KJC8 antibody. $\mathrm{H} 1299$ is a lung cancer cell line devoid of p53 gene expression (homozygous partial deletion of the p53 gene). SW620 and HT-29 are colon cancer cell lines expressing mutant p53. 293 cells are kidney cell lines expressing WT p53 inactivated by interaction with adenovirus E1B protein. U2OS is an osteosarcoma cell line expressing WT p53. MCF7 is a breast cancer cell line expressing WT p53. T47D is a breast cancer cell line expressing mutant p53. HCT-116 is a colon cancer line expressing WT p53. HCT-116-/- cell line derives from HCT-116 cells where the two p53 alleles have been sequentially disrupted by insertion in the exon 2 of two promoterless targeting vectors, each containing a geneticin- or hygromycin-resistance gene in place of genomic p53 sequences. HCT-116 - / cells have lost full-length p53 expression but still express p53 isoforms at the mRNA and protein levels as detected by $\mathrm{CM} 1$ and KJC8 antibodies $(\Delta 40 \mathrm{p} 53 \beta$ and $\Delta 133 \mathrm{p} 53 \beta)$. DO-1 antibody cannot detect p53 protein in HCT-116-/- because its epitope encoded by exon 2 has been disrupted. As the mouse monoclonal anti-p53 (1801) (epitope $46-55$ aa) can detect a p53 protein of $45 \mathrm{kDa}$ (data not shown), it suggests that translation of $\mathrm{p} 53$ protein has been initiated at codon 40. (d) Transcriptional activity of p53 protein isoforms on PG13-promoter. H1299 cells were cotransfected with the plasmid PG13-Luc containing the luciferase reporter gene driven by a p53-responsive promoter $(1 \mu \mathrm{g} / \mathrm{ml})$, a trace amount of pSVrenilla $(0.02 \mu \mathrm{g} / \mathrm{ml})$ as an internal control, and $0.5 \mu \mathrm{g} / \mathrm{ml}$ of indicated p53 isoform expression vector. In the experiments of co-expression of p53 with p53 isoforms, H1299 cells were cotransfected with the plasmid PG13-Luc $(1 \mu \mathrm{g} / \mathrm{ml})$, a trace amount of pSVrenilla $(0.02 \mu \mathrm{g} / \mathrm{ml})$ as an internal control, $0.5 \mu \mathrm{g} / \mathrm{ml}$ of WT p53 and an increasing concentration $(0.25,0.5 \mathrm{and} 1 \mu \mathrm{g} /$ $\mathrm{ml}$ ) of $\Delta \mathrm{Np} 53$ expression vector or $1 \mu \mathrm{g} / \mathrm{ml}$ of $\mathrm{p} 53 \beta$ or of $\Delta \mathrm{Np} 53 \beta$ expression vectors. The amount of SV-40 promoter was maintained constant at $2 \mu \mathrm{g} / \mathrm{ml}$ in each transfection by adding empty SV-40 expression vector. Luciferase activity was normalised to Renilla activity. Results shown are the average of four independent experiments performed in duplicate. S.D.'s are indicated as error bars. (e) p53 isoforms are defective in promoting apoptosis but $\Delta 133 p 53$ inhibits p53-mediated apoptosis. H1299 cells were transfected with $5 \mu \mathrm{g} / \mathrm{ml}$ of the indicated expression vector or empty SV-40 expression vector (sv). In the experiments of co-expression of p53 with p53 isoforms, $\mathrm{H} 1299$ cells were cotransfected with $5 \mu \mathrm{g} / \mathrm{ml}$ of p53 expression vector and $5 \mu \mathrm{g} / \mathrm{ml}$ of the indicated p53 isoforms expression vectors. The amount of SV-40 promoter was maintained constant at $10 \mu \mathrm{g} / \mathrm{ml}$ in each transfection by adding empty SV-40 expression vector. The DNA content of each transfected population was determined by flow cytometry analysis. The percentage of sub-G1 DNA content represents the percentage of apoptotic cells $48 \mathrm{~h}$ after transfection. The histogram represents the average of three independent transfections. S.D.'s are reported as error bars 
because of developmental abnormalities. In $23 \%$ of $p 53^{-1-}$ female embryos, the normal process of neural tube closure fails, leading to exencephaly and subsequent anencephaly. In addition, many of these embryos exhibit craniofacial malformations, including ocular abnormalities and defects in upper incisor tooth formation. These defects may arise either because p53 plays a physiological role at the time of neural tube closure or because of an abnormally high frequency of mutation within the haploid gametes of p53null parents. ${ }^{65,66}$

Knockin heterozygote p53 mice ( $p 53^{+/ \Delta N p 53}$ ) expressing amino-truncated p53 proteins are less susceptible to cancer than heterozygote $\mathrm{p} 53^{+/-}$mice but develop concomitant accelerated aging phenotype. Knockin homozygote mice $\left(p 53^{\Delta N p 53 / \Delta N p 53}\right.$, expressing only amino-truncated p53 proteins, are cancer-prone like $\mathrm{p} 53^{-l-}$ mice, and do not show any accelerated aging phenotype, indicating that that is dependent on the effect in trans of $\Delta \mathrm{Np53}$ on wild-type p53. ${ }^{67,68}$

Knockin heterozygote p53 mice $\left(\mathrm{p} 53^{+/ M}\right)$ expressing one mutant p53 allele, bearing a point mutation in the DNA binding domain, are as susceptible to cancer as heterozygote $\mathrm{p} 53^{+/-}$mice but do not show any accelerated aging phenotype. ${ }^{69,70}$ This indicates that $\Delta \mathrm{Np} 53$ proteins and point mutant p53, mutated in the DNA-binding domain, act a Immunoprecipitation of p53 protein isoforms

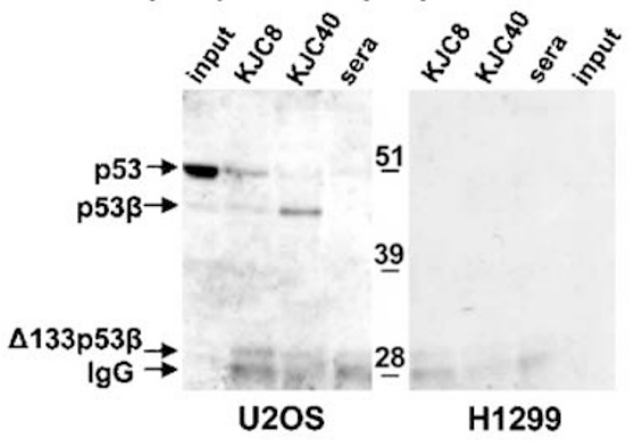

C

p53 isoforms expression in several cell lines

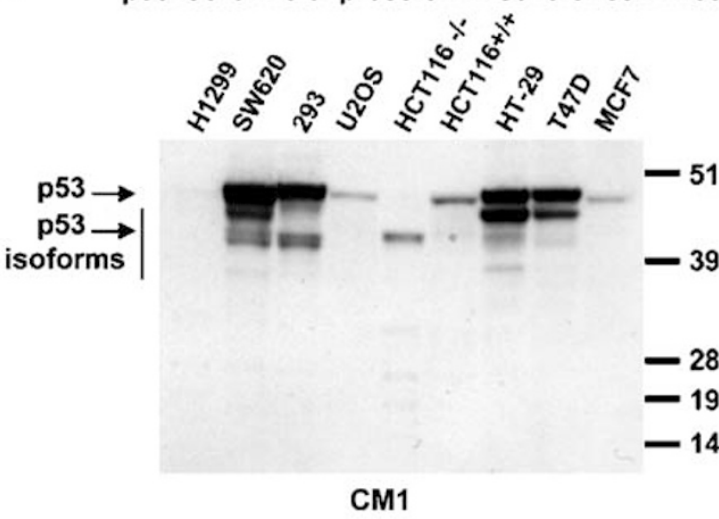

d Transcriptional activity of the p53 protein isoforms

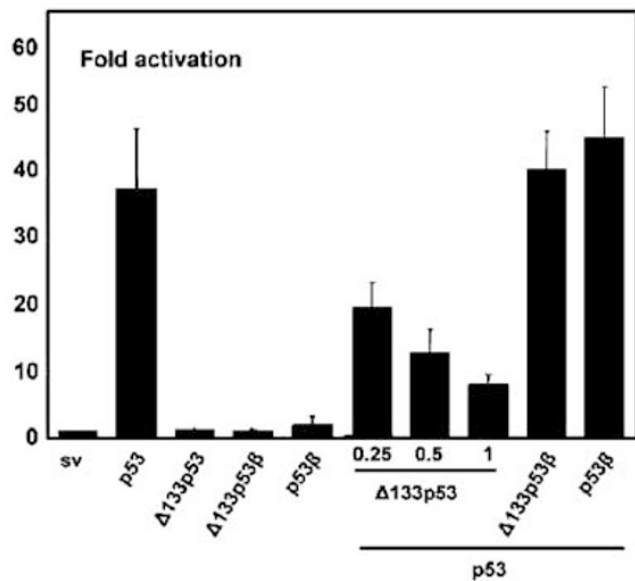

b 293 cells express several p53 protein isoforms

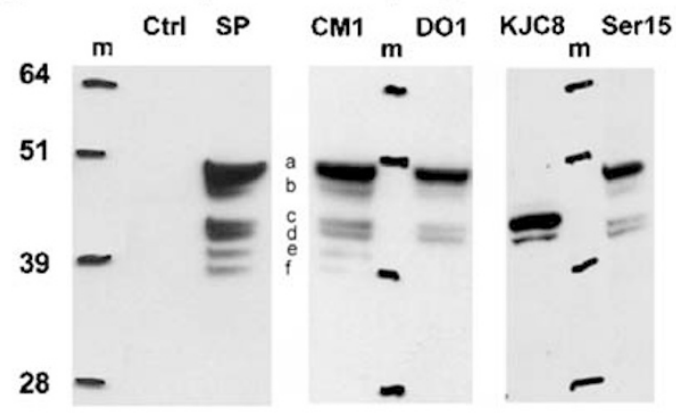

e Effect of p53 isoforms on apoptosis.

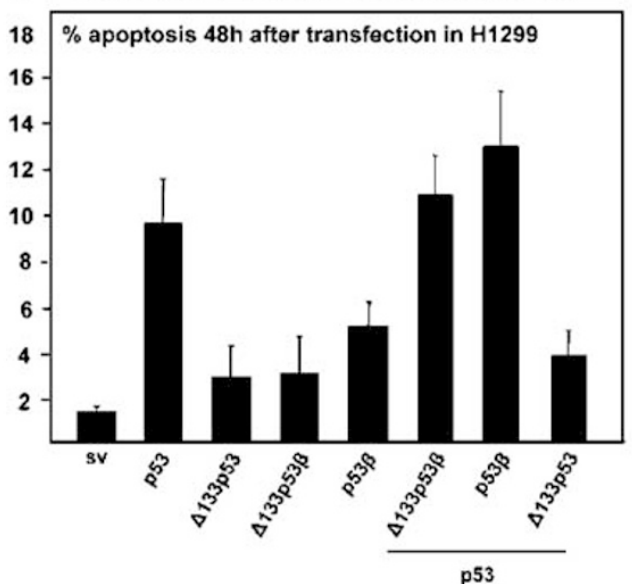


differentially towards wild-type p53 causing totally different phenotypes.

Furthermore, mice expressing additional copies of the entire p53 gene ('super p53' mice) do not show accelerated aging phenotype but are significantly more sensitive to ionising radiation and less cancer-prone than normal mice. ${ }^{71}$

Altogether, this suggests that the ratio $\Delta \mathrm{Np} 53 /$ full-length p53 (FLp53) are essential to tissue regeneration and longevity; this may be by affecting stem cells proliferation and tolerance to cellular damage. This hypothesis is supported by two recent publications. The authors ${ }^{58}$ report that a loss-offunction mutation in def gene in Zebrafish confers hypoplastic digestive organs and selectively upregulates the expression of $\Delta 113 p 53$ (homologue of human $\Delta 133 p 53$ ) but not p53. The increased expression of $\Delta 113 p 53$ selectively induces the expression of p53-target genes involved in cell cycle arrest but not in apoptosis, resulting in compromised organ growth in def mutant Zebrafish. This demonstrates that $\Delta 113 p 53$ can control in vivo p53 target gene expressions, and thus regulate tissue growth/organogenesis in Zebrafish. In another report, ${ }^{15}$ the authors show in human cells that $p 53 \beta$ can form a protein complex with p53 and binds preferentially to p21 and Bax promoters rather than to Mdm2 promoters. Co-expression of p53 $\beta$ with FLp53 enhances specifically Bax promoter activity, but not p21 promoter activity without affecting FLp53 level. This indicates that p53 $\beta$ enhances selectively p53 transcriptional activity on some promoters by not increasing FLp53 protein expression.

In humans, inactivation of p53 is the most common event in cancer and patients born with germ-line mutation in one allele of the p53 gene develop various cancers early in their life (Li-Fraumeni Syndrome). ${ }^{6}$ As p53 isoforms are encoded by exons different from FLp53, mutations occurring upstream of codon 133 or downstream of codon 331 would affect some p53 isoforms but not others. This may lead to the loss of some p53 biological activities, keeping others unaffected as it has already been observed for germ-line mutation of the p63 gene (see previously). It would be interesting to reanalyse p53 mutation in cancer and Li-Fraumeni syndrome in light of this.

One can wonder how p53 protein isoforms, which can be less abundant than FLp53, can modulate p53 biological activities. p53 protein is subject to post-translational modifications on multiple sites (phosphorylation, acetylation, methylation, ubiquitination, sumoylation and neddylation). Therefore, p53 protein is not expressed as a major unique protein but as a multitude of different post-translationally modified p53 proteins (Figure $3 c$ and Figure 4). Moreover, p53 binds p53 responsive element and induces gene expression as a tetramer (dimer of a dimer). ${ }^{72}$ As a result, p53 protein isoforms (p53 $\beta, \mathrm{p} 53 \gamma, \Delta 133 \mathrm{p} 53, \Delta 133 \mathrm{p} 53 \beta, \Delta 133 \mathrm{p} 53 \gamma \ldots$ ) may be abundant enough to interact directly or indirectly with specific subsets of post-translationally modified p53, to bind and regulate specific promoters or protein complexes. It is also possible that each p53 protein isoform have specific biological activities independent of FLp53. This may explain how p53 can be involved in the regulation of various biological functions (i.e. cell-cycle arrest, apoptosis, differentiation, replication, DNA repair, meiosis, mitosis, etc).

\section{Interplay Between p63/p73/p53 Isoforms}

Interaction between the family members and their isoforms may prove to be an extremely important aspect of cancer research. In this sense, there is evidence that the interaction between p53, p73 and p63 can be involved in carcinogenesis. p53 mutants, which have lost their tumour suppressor capacity, are significantly capable of binding and inactivating p73 isoforms. $^{69,70,73}$ Taken together, these findings imply that mutant p53 is not only able to disrupt the function of p53 itself, but that it is also able to inhibit the apoptotic function of TAp73.

\section{Interaction on Promoters of Target Genes}

The p53 protein family members interact with each other to induce a number of common target genes. The significance of p63 and p73 binding to p53-responsive promoters, and the importance of each family member, is demonstrated by the fact that p53 cannot induce apoptosis in response to DNA damage, without the presence of p63 and p73. ${ }^{74}$ In p63/p73 ${ }^{-1-}$ double null mouse embryo fibroblasts (MEFs), the apoptotic genes Bax, Noxa and PERP were not induced in response to DNA damage, while p21 induction was normal. p53 was absent at the Bax, Noxa and PERP promoters when p63 and p73 were not there. However, p63 could still bind these promoters in the absence of p53, suggesting that p63 is perhaps required for $\mathrm{p} 53$ to be recruited and function properly. Together, this illustrates that either p63 or p73 are vital for p53-induced apoptosis and, furthermore, that they themselves are an important component of the p53 tumour suppressor activity. ${ }^{25}$ Although the presence of p63 and p73 at p53-responsive promoters is significant, it will also be crucial to identify p63/p73 specific targets. Within the entire family, there are common and preferred gene targets and it will be essential to assess the functions of each of the isoforms, based on their binding to specific promoters or proteins.

\section{Interaction on p53, p63, p73 Promoters}

The p53 family members not only induce a number of common target genes but also they can regulate each other's expression. p53 and TAp73 can bind to the $\Delta \mathrm{Np} 73$ promoter (P2) and induce its transcription. ${ }^{75} \Delta \mathrm{Np} 73$ in turn inhibits p53 and TAp73 activity by competing for promoter sites or directly binding the proteins. Thus, a negative feedback loop is created, analogous to the p53/Mdm2 loop. It will be interesting to determine whether $p 53 / p 63 / p 73$ can bind to and regulate the internal promoter of $p 63$ or $p 53$, and whether this generates a feedback loop itself. Furthermore, it will be interesting to ascertain under what circumstances these feedback loops change to favour the expression of one isoform to another.

With this in mind, we may then be able to, for example, switch the $\mathrm{p} 53$ response from cell cycle arrest to apoptosis by altering the dynamics of the p53/p63/p73 isoforms.

The p53/p63/p73 family members are capable of interacting in many ways that involve direct or indirect protein interactions, regulation of same target gene promoter and regulation of each other's promoters. Although the proteins and their isoforms are expressed at various levels depending 
on tissue type and developmental stage, the presence of an isoform at low levels does not necessarily mean it is insignificant. The p53 family members and their isoforms can bind differentially to promoters and it may well prove that the ratio between isoforms is an important cell fate determinant. Further work on the interplay between the p53/p63/p73 proteins will be essential in understanding their individual and collective roles. The changes upon stimuli of the balance and interactions between the isoforms are likely to be fundamental to our understanding in the transition between normal cell cycling and the onset of tumour formation.

\section{Acknowledgements}

We thank Dr Borek Vojtesek for the production of the KJC8 and KJC40 antibodies. This work was supported by Cancer Research UK. Professor David Lane is a Gibb Fellow of Cancer Research UK.

\section{References}

1. Lane DP and Crawford LV (1979) T antigen is bound to a host protein in SV40-transformed cells. Nature 278: 261-263.

2. Linzer DIH and Levine AJ (1979) Characterization of a 54K dalton cellular SV40 tumor antigen present in SV40-transformed cells and in infected embryonal carcinoma cells. Cell 1: 43-52.

3. Melero JA, Stitt DT, Mangel WF and Carroll RB (1979) Identification of new polypeptide species (48-55 K) immunoprecipitable by antiserum to purified large $\mathrm{T}$ antigen and present in simian virus 40 -infected and transformed cells. J. Virol. 93: 466-480.

4. Kress M, May E, Cassingena R and May $P$ (1979) Simian virus 40transformed cells express new species of proteins precipitable by anti-simian virus 40 tumor serum. J. Virol. 31: 472-483.

5. De Leo AB, Jay G, Appella E, Dubois GC, Law LW and Old LJ (1979) Detection of a transformation-related antigen in chemically induced sarcomas and other transformed cells of the mouse. Proc. Natl. Acad. Sci. USA 76: 2420-2424

6. Oren M (2003) Decision making by p53: life, death and cancer. Cell Death Differ. 10: 431-442.

7. Lane DP (1992) Cancer. p53, guardian of the genome (news; comment) (see comments). Nature 358: 15-16.

8. El-Deiry WS, Kern SE, Pietenpol JA, Kinzler KW and Vogelstein B (1992) Definition of a consensus binding site for p53. Nat. Genet. 1: 45-49.

9. Bourdon JC, Deguin-Chambon V, Lelong JC, Dessen P, May P, Debuire B and May E (1997) Further characterisation of the p53 responsive element identification of new candidate genes for trans-activation by p53. Oncogene 14: 85-94.

10. El-Deiry WS, Tokino T, Velculescu VE, Levy DB, Parsons R, Trent JM, Lin D, Mercer WE, Kinzler KW and Vogelstein B (1993) WAF1, a potential mediator of p53 tumor suppression. Cell 75: 817-825.

11. Nakano K and Vousden KH (2001) PUMA, a novel proapoptotic gene, is induced by p53. Mol. cell. 7: 683-694.

12. Bourdon JC, Renzing J, Robertson PL, Fernandes KN and Lane DP (2002) Scotin, a novel p53-inducible proapoptotic protein located in the ER and the nuclear membrane. J. Cell. Biol. 158: 235-246.

13. Yang A, Kaghad M, Wang $Y$, Gillett $E$, Fleming MD, Dotsch $V$, Andrews NC Caput $D$ and McKeon $F$ (1998) p63, a p53 homolog at 3q27-29, encodes multiple products with transactivating, death-inducing, and dominant-negative activities. Mol. Cell 2: 305-316.

14. Kaghad M, Bonnet $H$, Yang $A$, Creancier L, Biscan JC, Valent A, Minty $A$ Chalon P, Lelias JM, Dumont X, Ferrara P, McKeon F and Caput D (1997) Monoallelically expressed gene related to $p 53$ at $1 p 36$, a region frequently deleted in neuroblastoma and other human cancers. Cell 90: 809-819.

15. Bourdon JC, Fernandes K, Murray-Zmijewski F, Liu G, Diot A, Xirodimas DP Saville MK and Lane DP (2005) p53 isoforms can regulate p53 transcriptional activity. Genes Dev. 19: 2122-2137.
16. Stamm S, Ben-Ari S, Rafalska I, Tang Y, Zhang Z, Toiber D, Thanaraj TA and Soreq $H$ (2005) Function of alternative splicing. Gene 344: 1-20.

17. McKeon $F$ (2004) p63 and the epithelial stem cell: more than status quo? Genes Dev. 18: 465-469.

18. Osada M, Park HL, Nagakawa Y, Yamashita K, Fomenkov A, Kim MS, Wu G, Nomoto S, Trink B and Sidransky D (2005) Differential recognition of response elements determines target gene specificity for p53 and p63. Mol. Cell. Biol. 25: 6077-6089.

19. Sasaki Y, Naishiro Y, Oshima Y, Imai K, Nakamura Y and Tokino T (2005) Identification of pigment epithelium-derived factor as a direct target of the p53 family member genes. Oncogene 24: 5131-5136.

20. Benard J, Douc-Rasy S and Ahomadegbe JC (2003) TP53 family members and human cancers. Hum. Mutat. 21: 182-191.

21. Dohn M, Zhang S and Chen X (2001) p63alpha and DeltaNp63alpha can induce cell cycle arrest and apoptosis and differentially regulate p53 target genes. Oncogene 20: 3193-3205.

22. Wu G, Nomoto S, Hoque MO, Dracheva T, Osada M, Lee CC, Dong SM, Guo Z, Benoit N, Cohen Y, Rechthand P, Califano J, Moon CS, Ratovitski E, Jen J, Sidransky D and Trink B (2003) DeltaNp63alpha and TAp63alpha regulate transcription of genes with distinct biological functions in cancer and development. Cancer Res. 63: 2351-2357.

23. Koster MI, Kim S, Mills AA, DeMayo FJ and Roop DR (2004) p63 is the molecular switch for initiation of an epithelial stratification program. Genes Dev. 18: 126-131.

24. Mills AA (2006) p63: oncogene or tumor suppressor? Curr. Opin. Genet. Dev. 16: 38-44.

25. Flores ER, Sengupta S, Miller JB, Newman JJ, Bronson R, Crowley D, Yang A, McKeon $F$ and Jacks T (2005) Tumor predisposition in mice mutant for p63 and p73: evidence for broader tumor suppressor functions for the p53 family. Cancer Cell 7: 363-373.

26. Keyes WM, Wu Y, Vogel H, Guo X, Lowe SW and Mills AA (2005) p63 deficiency activates a program of cellular senescence and leads to accelerated aging. Genes Dev. 19: 1986-1999.

27. Massion PP, Taflan PM, Jamshedur Rahman SM, Yildiz P, Shyr Y, Edgerton ME, Westfall MD, Roberts JR, Pietenpol JA, Carbone DP and Gonzalez AL (2003) Significance of p63 amplification and overexpression in lung cancer development and prognosis. Cancer Res. 63: 7113-7121.

28. Wang TY, Chen BF, Yang YC, Chen H, Wang Y, Cviko A, Quade BJ, Sun D, Yang A, McKeon FD and Crum CP (2001) Histologic and immunophenotypic classification of cervical carcinomas by expression of the p53 homologue p63: a study of 250 cases. Hum. Pathol. 32: 479-486.

29. Pruneri G, Fabris S, Dell'Orto P, Biasi MO, Valentini S, Del Curto B, Laszlo D, Cattaneo L, Fasani R, Rossini L, Manzotti M, Bertolini F, Martinelli G, Neri A and Viale $G$ (2005) The transactivating isoforms of p63 are overexpressed in high-grade follicular lymphomas independent of the occurrence of p63 gene amplification. J. Pathol. 206: 337-345.

30. Nylander K, Vojtesek B, Nenutil R, Lindgren B, Roos G, Zhanxiang W, Sjostrom B, Dahlqvist A and Coates PJ (2002) Differential expression of p63 isoforms in normal tissues and neoplastic cells. J. Pathol. 198: 417-427.

31. Mills AA, Zheng B, Wang XJ, Vogel H, Roop DR and Bradley A (1999) p63 is a p53 homologue required for limb and epidermal morphogenesis (in Process Citation). Nature 398: 708-713.

32. Celli J, Duijf $P$, Hamel BC, Bamshad M, Kramer B, Smits AP, Newbury-Ecob R, Hennekam RC, Van Buggenhout G, van Haeringen A, Woods CG, van Essen AJ, de Waal R, Vriend G, Haber DA, Yang A, McKeon F, Brunner HG and van Bokhoven $\mathrm{H}$ (1999) Heterozygous germline mutations in the p53 homolog p63 are the cause of EEC syndrome. Cell 99: 143-153.

33. van Bokhoven $H$, Hamel BC, Bamshad M, Sangiorgi E, Gurrieri F, Duijf PH, Vanmolkot KR, van Beusekom E, van Beersum SE, Celli J, Merkx GF, Tenconi R, Fryns JP, Verloes A, Newbury-Ecob RA, Raas-Rotschild A, Majewski F, Beemer FA, Janecke A, Chitayat D, Crisponi G, Kayserili $H$, Yates JR, Neri G and Brunner HG (2001) p63 Gene mutations in eec syndrome, limb-mammary syndrome, and isolated split handsplit foot malformation suggest a genotype-phenotype correlation. Am. J. Hum. Genet. 69: 481-492.

34. Duijf PH, Vanmolkot KR, Propping P, Friedl W, Krieger E, McKeon F, Dotsch $\mathrm{V}$, Brunner $\mathrm{HG}$ and van Bokhoven $\mathrm{H}$ (2002) Gain-of-function mutation in ADULT syndrome reveals the presence of a second transactivation domain in p63. Hum. Mol. Genet. 11: 799-804. 
35. McGrath JA, Duijf $P H$, Doetsch V, Irvine $A D$, de Waal $R$, Vanmolkot $K R$, Wessagowit V, Kelly A, Atherton DJ, Griffiths WA, Orlow SJ, van Haeringen A Ausems MG, Yang A, McKeon F, Bamshad MA, Brunner HG, Hamel BC and van Bokhoven $H$ (2001) Hay-Wells syndrome is caused by heterozygous missense mutations in the SAM domain of p63. Hum. Mol. Genet. 10: 221-229.

36. Moll UM and Slade N (2004) p63 and p73: roles in development and tumor formation. Mol. Cancer Res. 2: 371-386.

37. Melino G, Lu X, Gasco M, Crook T and Knight RA (2003) Functional regulation of p73 and p63: development and cancer. Trends Biochem. Sci. 28: 663-670.

38. Stiewe T, Zimmermann S, Frilling A, Esche H and Putzer BM (2002) Transactivation-deficient DeltaTA-p73 acts as an oncogene. Cancer Res. 62 : 3598-3602

39. Liu G, Nozell S, Xiao H and Chen X (2004) DeltaNp73beta is active in transactivation and growth suppression. Mol. Cell. Biol. 24: 487-501.

40. Pozniak CD, Radinovic S, Yang A, McKeon F, Kaplan DR and Miller FD (2000) An anti-apoptotic role for the p53 family member, p73, during developmental neuron death. Science 289: 304-306.

41. Saifudeen Z, Diavolitsis V, Stefkova J, Dipp S, Fan H and El-Dahr SS (2005) Spatiotemporal switch from DeltaNp73 to TAp73 isoforms during nephrogenesis: impact on differentiation gene expression. J. Biol. Chem. 280: 23094-23102.

42. De Laurenzi V, Costanzo A, Barcaroli D, Terrinoni A, Falco M, AnnicchiaricoPetruzzelli M, Levrero M and Melino G (1998) Two new p73 splice variants, gamma and delta, with different transcriptional activity. J. Exp. Med. 188 1763-1768.

43. Tschan MP, Grob TJ, Peters UR, Laurenzi VD, Huegli B, Kreuzer KA, Schmidt CA, Melino G, Fey MF, Tobler A and Cajot JF (2000) Enhanced p73 expression during differentiation and complex p73 isoforms in myeloid leukemia. Biochem. Biophys. Res. Commun. 277: 62-65.

44. De Laurenzi V, Rossi A, Terrinoni A, Barcaroli D, Levrero M, Costanzo A, Knight RA, Guerrieri P and Melino G (2000) p63 and p73 transactivate differentiation gene promoters in human keratinocytes. Biochem. Biophys. Res. Commun. 273: 342-346.

45. Yang A, Walker N, Bronson R, Kaghad M, Oosterwegel M, Bonnin J, Vagner C, Bonnet H, Dikkes P, Sharpe A, McKeon F and Caput D (2000) p73deficient mice have neurological, pheromonal and inflammatory defects but lack spontaneous tumours. Nature 404: 99-103.

46. Fillippovich I, Sorokina N, Gatei M, Haupt Y, Hobson K, Moallem E, Spring K, Mould M, McGuckin MA, Lavin MF and Khanna KK (2001) Transactivationdeficient p73alpha (p73Deltaexon2) inhibits apoptosis and competes with p53. Oncogene 20: 514-522.

47. Concin N, Becker K, Slade N, Erster S, Mueller-Holzner E, Ulmer H, Daxenbichler G, Zeimet A, Zeillinger R, Marth C and Moll UM (2004) Transdominant DeltaTAp73 isoforms are frequently up-regulated in ovarian cancer. Evidence for their role as epigenetic p53 inhibitors in vivo. Cancer Res. 64: 2449-2460.

48. Casciano I, Mazzocco K, Boni L, Pagnan G, Banelli B, Allemanni G, Ponzoni M, Tonini GP and Romani M (2002) Expression of DeltaNp73 is a molecular marker for adverse outcome in neuroblastoma patients. Cell Death Differ. 9: 246-251.

49. Flaman J-M, Waridel F, Estreicher A, Vannier A, Limacher J-M, Gilbert D, Iggo $\mathrm{R}$ and Frebourg $\mathrm{T}$ (1996) The human tumor suppressor gene p53 is alternatively spliced in normal cells. Oncogene 12: 813-818.

50. Chow VT, Quek HH and Tock EP (1993) Alternative splicing of the p53 tumor suppressor gene in the Molt-4 T-lymphoblastic leukemia cell line. Cancer Lett. 73: 141-148.

51. Yin Y, Stephen CW, Luciani MG and Fahraeus R (2002) p53 Stability and activity is regulated by Mdm2-mediated induction of alternative p53 translation products. Nat. Cell Biol. 4: 462-467.

52. Ghosh A, Stewart D and Matlashewski G (2004) Regulation of human p53 activity and cell localization by alternative splicing. Mol. Cell Biol. 24: 7987-7997.

53. Zhu J, Zhou W, Jiang $\mathrm{J}$ and Chen $X$ (1998) Identification of a novel p53 functional domain that is necessary for mediating apoptosis. J. Biol. Chem. 273: $13030-13036$.

54. Mills AA (2005) p53: link to the past, bridge to the future. Genes Dev. 19: 2091-2099.

55. Rohaly G, Chemnitz J, Dehde S, Nunez AM, Heukeshoven J, Deppert W and Dornreiter I (2005) A novel human p53 isoform is an essential element of the ATR-intra-S phase checkpoint. Cell 122: 21-32.
56. Ollmann M, Young LM, Di Como CJ, Karim F, Belvin M, Robertson S, Whittaker K, Demsky M, Fisher WW, Buchman A, Duyk G, Friedman L, Prives C and Kopczynski C (2000) Drosophila p53 is a structural and functional homolog of the tumor suppressor p53. Cell 101: 91-101.

57. Brodsky MH, Nordstrom W, Tsang G, Kwan E, Rubin GM and Abrams JM (2000) Drosophila p53 binds a damage response element at the reaper locus. Cell 101: 103-113.

58. Chen J, Ruan H, Ng SM, Gao C, Soo HM, Wu W, Zhang Z, Wen Z, Lane DP and Peng $J$ (2005) Loss of function of def selectively up-regulates Delta113p53 expression to arrest expansion growth of digestive organs in zebrafish. Genes Dev. 19: 2900-2911.

59. Wolf D, Admon S, Oren M and Rotter V (1984) Abelson murine leukemia virus-transformed cells that lack p53 protein synthesis express aberrant p53 mRNA species. Mol. Cell Biol. 4: 552-558.

60. Almog N, Goldfinger N and Rotter V (2000) p53-dependent apoptosis is regulated by a C-terminally alternatively spliced form of murine p53. Oncogene 19: 3395-3403.

61. Wu Y, Liu Y, Lee L, Miner Z and Kulesz-Martin M (1994) Wild-type alternatively spliced p53: binding to DNA and interaction with the major p53 protein in vitro and in cells. EMBO J. 13: 4823-4830.

62. Laverdiere M, Beaudoin J and Lavigueur A (2000) Species-specific regulation of alternative splicing in the C-terminal region of the p53 tumor suppressor gene. Nucleic Acids Res. 28: 1489-1497.

63. Will K, Warnecke G, Bergmann S and Deppert W (1995) Species- and tissuespecific expression of the C-terminal alternatively spliced form of the tumor suppressor p53. Nucleic Acids Res. 23: 4023-4028.

64. Donehower LA, Harvey M, Slagle BL, McArthur MJ, Montgomery Jr CA Butel JS and Bradley A (1992) Mice deficient for p53 are developmentally normal but susceptible to spontaneous tumours. Nature 356: 215-221.

65. Armstrong JF, Kaufman MH, Harrison DJ and Clarke AR (1995) Highfrequency developmental abnormalities in p53-deficient mice. Curr. Biol. 5 931-936.

66. Sah VP, Attardi LD, Mulligan GJ, Williams BO, Bronson RT and Jacks T (1995) A subset of p53-deficient embryos exhibit exencephaly. Nat. Genet. 10: $175-180$.

67. Tyner SD, Venkatachalam S, Choi J, Jones S, Ghebranious N, Igelmann H, Lu X, Soron G, Cooper B, Brayton C, Hee Park S, Thompson T, Karsenty G, Bradley A and Donehower LA (2002) p53 mutant mice that display early ageing-associated phenotypes. Nature 415: 45-53.

68. Maier B, Gluba W, Bernier B, Turner T, Mohammad K, Guise T, Sutherland A, Thorner $M$ and Scrable $H$ (2004) Modulation of mammalian life span by the short isoform of p53. Genes Dev. 18: 306-319.

69. Lang GA, Iwakuma T, Suh YA, Liu G, Rao VA, Parant JM, Valentin-Vega YA, Terzian T, Caldwell LC, Strong LC, El-Naggar AK and Lozano G (2004) Gain of function of a p53 hot spot mutation in a mouse model of Li-Fraumeni syndrome. Cell 119: 861-872.

70. Olive KP, Tuveson DA, Ruhe ZC, Yin B, Willis NA, Bronson RT, Crowley D and Jacks $T$ (2004) Mutant p53 gain of function in two mouse models of LiFraumeni syndrome. Cell 119: 847-860.

71. Garcia-Cao I, Garcia-Cao M, Martin-Caballero J, Criado LM, Klatt P, Flores JM, Weill JC, Blasco MA and Serrano M (2002) 'Super p53' mice exhibit enhanced DNA damage response, are tumor resistant and age normally. EMBO J. 21: 6225-6235.

72. Clore GM, Ernst J, Clubb R, Omichinski JG, Kennedy WM, Sakaguchi K, Appella E and Gronenborn AM (1995) Refined solution structure of the oligomerization domain of the tumour suppressor p53 (see comments). Nat. Struct. Biol. 2: 321-333

73. Strano S, Munarriz E, Rossi M, Cristofanelli B, Shaul Y, Castagnoli L, Levine AJ, Sacchi A, Cesareni G, Oren M and Blandino G (2000) Physical and functional interaction between p53 mutants and different isoforms of p73. J. Biol. Chem. 275: 29503-29512.

74. Flores ER, Tsai KY, Crowley D, Sengupta S, Yang A, McKeon F and Jacks T (2002) p63 and p73 are required for p53-dependent apoptosis in response to DNA damage. Nature 416: 560-564.

75. Grob TJ, Novak U, Maisse C, Barcaroli D, Luthi AU, Pirnia F, Hugli B, Graber HU, De Laurenzi V, Fey MF, Melino G and Tobler A (2001) Human delta Np73 regulates a dominant negative feedback loop for TAp73 and p53. Cell Death Differ. 8: 1213-1223. 